\title{
Assessment of geological factors responsible for gas entrapment in two nigerian coals and syngas extraction using locally fabricated gasification plant
}

Olugbenga Ajayi Ehinola

University of Ibadan https://orcid.org/0000-0002-7185-7672

Kehinde Joseph Egunjobi ( $\nabla$ khennybless@gmail.com )

https://orcid.org/0000-0002-6846-6312

Ibrahim Adedayo Oladosu

University of Ibadan

Olugbenga Adebanjo Falode

university of Ibadan

Oladotun Afolabi Oluwajana

Adekunle Ajasin University Akungba

Research

Keywords: coal, samples, okaba, syngas, gasification, plant

Posted Date: October 25th, 2021

DOI: https://doi.org/10.21203/rs.3.rs-961605/v1

License: (c) (7) This work is licensed under a Creative Commons Attribution 4.0 International License. Read Full License 


\section{Abstract}

Of all the fossil fuel sources, Coal Bed Methane (CBM) is the least expensive for its energy content. This study aimed at assessing the geological factors that may be responsible for gas emplacement in Nigerian coal and syngas extraction using a locally fabricated gasification plant. Trace element, sulfur content, $\mathrm{X}$ Ray diffraction, and Scan Electron Microscope analysis of coal samples from Ute and Okaba were carried out to determine geological factors such as depositional environment, mineralogy, and pore morphology that affects the emplacement of gas in coals and its extraction. The syngas was then extracted from Okaba and Ute coal using the fabricated gasification plant which consists of a reactor, water jacket to regulate body temperature, a blower to allow continuous inflow of air, cyclone filter to filter the syngas from the impurity, compressor, and a cylinder to collect and store the gas. The coal samples were heated to a temperature range of $500-1000^{\circ} \mathrm{C}$. The value of the $\mathrm{V} / \mathrm{Ni}$ ratio of the coals ranged from 0.35 to $3.75 \mathrm{ppm}$. Also, plots of $\mathrm{V} / \mathrm{Cr}$ and $\mathrm{Ni} / \mathrm{Co}$ ratios indicated predominantly oxic conditions during sediment accumulation. The low $\mathrm{V} /(\mathrm{V}+\mathrm{Ni})$ ratio $(0.26-0.0 .79 \mathrm{ppm})$ also confirmed that the coal samples were deposited under oxic conditions. By implication, the sulfur content in the Okaba and Ute coal with the range of $0.85-2.33 \%$ originated from parent plant material deposited in a lacustrine environment. The coal samples contain brittle minerals such as quartz and Kaolinitic clay that also allow the creation of natural fractures and could provide induced fractures under artificial fracturing force which is conducive to coal gas exploration. The pore and fracture diameters observed in coal samples from Okaba and Ute are classified as microfracture and macropores, respectively, implying that the coal can serve as a reservoir for coal bed methane (CBM) and that the linkage of the fractures and pores results in high permeability which in turn will allow the coal to easily release the gas it is storing when heated. The syngas extracted from Okaba and Ute coal consists of a mixture of $\mathrm{N}_{2}, \mathrm{H}_{2}, \mathrm{CO}_{2}$, and $\mathrm{CH}_{4}$ which can either be used upon purification for transport, chemicals production, heat, and power generation. It can be deduced that the coal samples from the study area (Okaba and Ute) are capable of storing gas which in turn can be extracted and used by gasification method which has a minimal environmental effect because the gasification plant reduces $\mathrm{CO}_{2}$ emission by $90 \%$ as compared with direct combustion of coal.

\section{Introduction}

Crude oil, natural gas, coal, tar sands, biomass, and other renewable energy resources such as geothermal, solar, tidal, and wind energy, as well as a substantial hydroelectric energy potential, make up Nigeria's energy resources. These resources provide the country the chance to prosper with a diverse energy mix. The energy sector, on the other hand, has not made use of this natural resource. The advancement of oil and gas usage and development over the last fifty years has given the perception that hydrocarbon is the only viable energy medium accessible to the country. This has had a negative influence on the complete evaluation and utilization of all of Nigeria's energy resources. Energy must be created from a range of sources to guarantee that Nigerians have a stable and resilient energy supply at a reasonable cost.

Coal is an organic sedimentary rock formed from a variety of plant components and tissues that were deposited in more or less aquatic environments (Loison et al., 1989). Nigeria's coal reserves are estimated to be 2.75 billion tonnes, with occurrences spread across 13 states (NCC, 1997$)$. Coal has been found in the lower (LBC), middle (MBC), and upper (UBC) Benue Troughs (Wilson and Bain, 1928; Simpson, 1954; Akande et al., 1992; Obaje et al., 2004; Ehinola et al., 2002). The Chad basin, which is stratigraphically and structurally linked to the Benue and Anambra basins, is another prospective coal-producing region (Ford, 1981). Garin Maigangu (Bauchi), Afikpo region (Abia), Koton - Karfi (Kogi), Ute (Ondo), and many more are smaller occurrences (NCC, 1982, Ehinola et al., 2012). Coal Exploration and exploitation are now underway, notably at the underground mines of Okpara and Onyeama. The Okaba surface mine and the Orukpa underground mine (in MBC) have been expanded to diversify the economy, which is nearly entirely reliant on oil and gas (Obaje and Ligouis, 1996, Obaje et al., 1999). Over the year, coal has received a lot of interest as an alternative energy source. However, some geological factors such as paleo oxidation condition, depositional environment, pore morphology, and mineral content might be responsible for syngas entrapment in coal. Direct combustion of coal may result in environmental pollution. Hence, the need to examine some properties of some Nigerian coals and their implication on syngas extraction. This study is aimed at the examination of geological factors responsible for gas emplacement and gasification of coals from Nigeria using a locally fabricated plant.

\section{Materials And Methods}

Coal samples from Okaba Southeastern Nigeria and Ute Southwestern Nigeria (Fig. 1) were collected for this study and the hand specimen was studied for trace element, mineralogical, and pore morphological analysis and further utilized for syngas extraction using a locally fabricated gasification plant. The sample from Okaba was collected from Okaba coal mine belonging to the Lower Coal Measure of the Mamu Formation. The lithologic assemblage of the Okaba coal is dominated by coal and carbonaceous shale (Fig. 3). Samples from Ute belongs to the Abeokuta Formation with a lithological assemblage consisting of mainly coal and siltstone (Fig. 2)

The laboratory analysis involves trace element analysis, sulphur content analysis, X-ray Diffraction (XRD) analysis, and Scanning Electron Microscopy (SEM).

\subsection{Trace element analysis}

The weight of crushed samples measured was between 0.1 to $0.2 \mathrm{~g}$ and put into a PTFE digestion container. 2.0 ml of concentrated nitric acid (Merck, Germany) was added to each container and allowed to stay overnight. $1.0 \mathrm{ml}$ of $30 \%$ hydrogen peroxide (Beijing Chemical Company, China) was added and $0.5 \mathrm{ml}$ of hydrofluoric acid was later added. The container was placed in a stainless-steel bomb and then sealed with a screw closure to avoid leakage and placed in an oven. The oven temperature was kept at $180^{\circ} \mathrm{C}$ for $10 \mathrm{~h}$. After cooling to room temperature, the solution was transferred into a $25 \mathrm{ml} \mathrm{PET} \mathrm{bottle}$ and diluted with milli-Q water. Reagent blanks were processed simultaneously to deduct the error induced by the analytical procedure. The sample solution and the blank were analyzed for $\mathrm{As}, \mathrm{Ba}, \mathrm{Se}, \mathrm{Pb}, \mathrm{Cd}, \mathrm{Ni}, \mathrm{Cr}, \mathrm{Co}, \mathrm{Mo}, \mathrm{Mn}, \mathrm{Cu}, \mathrm{V}$, and $\mathrm{Zn}$ using inductively coupled plasma-mass spectrometry (ICP-MS Agilent 7500 series, Octopole Reaction System), while Hg was determined by an atomic fluorescence spectrometer (AFS - AF-620, Beijing Reyleigh Analytical Instrument Company, China) after hydride generation. The analysis was duplicated to verify the precision of the method of digestion. 


\subsection{Total Sulfur Content Analysis}

The total sulfur was determined following ASTM Standards D3177-02. Samples were crushed and sieved to $200 \mu \mathrm{m}$. 0.498 to $0.510 \mu \mathrm{g}$ was weighed into the sample holder. High sulfur coal ashTW-10 was used to balance the equipment (a micro-computerized rapid test instrument for total sulfur manufactured by Hebi Huatai Benga Instrument measuring appliances Ltd., China). The samples were heated to $1050 \mathrm{OC}$ and total sulfur was recorded. The standard reference material was also weighed and tungsten W oxide (from Kermel Company Tianjin, China) was added to each sample before loading automatically into the machine.

\subsection{Mineralogical analysis}

The mineralogical phases were determined by powder X-ray diffraction (XRD) and scanning electron microscope (SEM). This was used to study the characteristics of the minerals and to determine the distribution of some elements in the coal.

\subsection{Procedures for Coal Gasification (Syngas Extraction)}

Two runs were made for different coals of Okaba and Ute, at the initial stage charcoal is used to provide heat for the burning purpose of coal, and once the burning of coal starts the coal act as a burning source for the remaining amount of coal. As a result of heat conduction across the gasifier walls, steam is generated in the water jacket which is transferred to the gasifier chamber with help of the blower, the blower also provides air for burning purposes. Due to the chemical reaction of coal and steam, synthetics gas is produced which is the combination of many gases, at this stage the gas consists of many impurities like water and dust particle. To remove these impurities, the gas is passed through a cyclone filter which removes the impurities to a significant amount, and at the exit of the cyclone filter, the pure synthetics gas is collected into a cylinder with the aid of a compressor as shown in Fig. $4 \mathrm{a}$ and $\mathrm{b}$.

\section{Results And Discussion 3.1 Geochemistry}

The trace element and mineralogical composition of the lithologic units are given in Tables 1 and 2 respectively. The coal comprises pyrite, amorphous, and clays (Table 4.2). Quartz, copper, and zinc are also observed in the SEM result.

\subsubsection{Trace Element Concentration}

The total concentration of trace elements in coals samples from the study area is represented in Table 1. Among all the trace elements in the coal samples studied, Ba was the highest (22.68-78.63 ppm), followed by $\mathrm{Cr}$ (10.92-37.75 ppm), Zn (3.10-24.35 ppm), Ni (3.47-27.32 ppm), V (9.68-13.01 ppm), Cu (6.13$7.30 \mathrm{ppm})$ and $\mathrm{Pb}(3.48-5.15 \mathrm{ppm})$. The trace elements analyzed can be grouped into compatible and incompatible (Ajayi et al., 2006). The compatible trace elements include $\mathrm{Cr}$, $\mathrm{Ni}$, and $\mathrm{Zn}$ while the remaining elements ( $\mathrm{As}, \mathrm{Ba}, \mathrm{Cd}, \mathrm{Co}, \mathrm{Cu}, \mathrm{Hg}, \mathrm{Mn}, \mathrm{Pb}, \mathrm{Se}, \mathrm{Mo}$, and $\mathrm{V}$ ) are incompatible.

\subsubsection{Paleoredox depositional conditions}

Trace element concentrations in coal have been used by different authors (Hart and Leahy, 1983; Swaine, 1983; Orem and Finkelman, 2003) as indicators of depositional environments. Chou $(1984)$ and Goodarzi $(1987,1988)$ studied geochemistry, concentration, and elemental distribution in coal seams and cited elements such as $\mathrm{Mo}, \mathrm{Mg}, \mathrm{B}, \mathrm{Cl}, \mathrm{Br}, \mathrm{Na}, \mathrm{Y}$, and $\mathrm{U}$ as indicators of marine influence. Redox-sensitive elements $\mathrm{Mo}, \mathrm{U}, \mathrm{V}, \mathrm{Cr}, \mathrm{Fe}, \mathrm{Mn}, \mathrm{Ni}, \mathrm{Co}, \mathrm{Ba}, \mathrm{Pb}, \mathrm{Cd}, \mathrm{Zn}, \mathrm{Cu}, \mathrm{and}$ their ratios have been used to assess paleoredox depositional conditions in sedimentary rocks (Algeo and Maynard, 2004; Tribovillard et al., 2006; Saez et al., 2011). In this study, $\mathrm{V} /(\mathrm{V}+\mathrm{Ni}), \mathrm{V} / \mathrm{Cr}, \mathrm{Ni} / \mathrm{Co}, \mathrm{V} / \mathrm{Ni}$, and $\mathrm{Cu} / \mathrm{Zn}$ were used to evaluate the paleoredox conditions of depositional environments during sediment accumulation. According to Jones and Manning (1994), Ni/Co ratios < 5 and V/Cr ratios < 2 suggest oxic conditions; 5-7 and 2-4.25 (dysoxic conditions) and > 7 and $>4.25$ (suboxic to anoxic conditions) respectively. The $\mathrm{Ni} / \mathrm{Co}$ and $\mathrm{V} / \mathrm{Cr}$ ratios of the Okaba coal sample have a value of 2.12 and 1.19 respectively while The $\mathrm{Ni} / \mathrm{Co}$ and $\mathrm{V} / \mathrm{Cr}$ ratios of the Ute coal sample have a value of 7.61 and 0.26 respectively (Table 2), indicating mainly oxic depositional environment for Okaba coal and oxic - suboxic for Ute coal. Hatch and Leventhal (1992), proposed V/(V+Ni) ratios > 0.84 for euxinic conditions, $0.54-0.82$ (anoxic waters) and $0.46-0.60$ (dysoxic conditions). Therefore, $\mathrm{V} /(\mathrm{V}+\mathrm{Ni})$ can be related to redox conditions in source rock's depositional environment (Moldowan et al., 1986 ; Hatch and Leventhal, 1992; Killops and Killops 2005; Peters et al., 2005). Low V/(V+Ni) porphyrin ratios in marine Toarcian rocks reflect oxic suboxic conditions, while high ratios reflect anoxic sedimentation (Moldowan et al., 1986; Killops and Killops 2005). The concentrations of vanadium in the Okaba and Ute coal is $13.01 \mathrm{ppm}$ and $9.68 \mathrm{ppm}$ respectively as shown in (Table 1). The low vanadium content of the coal suggests a low mature and marine/terrestrial sourced coal (Adedosu et al., 2007). Low V/Ni ratios (<0.5) are expected for petroleum-derived from marine organic matter, with high to moderate sulphur content, while $\mathrm{V} / \mathrm{Ni}$ ratios (1-10) are expected from petroleum-derived from lacustrine and terrestrial organic matter (Barwise, 1990). The value of the $\mathrm{V} / \mathrm{Ni}$ ratio of the studied coal ranges from 0.35 to 3.75 (Table 2). The source rock depositional environment determines the proportionality of vanadium to nickel. The $\mathrm{V} / \mathrm{Ni}$ ratios (0.35 to 3.75; Table 2) for the coal samples suggest the same depositional environment. Also, plots of V/Cr and Ni/Co ratios (table 4.1 and Fig. 4.3a); Jones and Manning, 1994) indicate predominantly oxic conditions during sediment accumulation. Based on Hatch and Leventhal (1992) published thresholds, the $\mathrm{V} /(\mathrm{V}+\mathrm{Ni})$ ratios for the Okaba and Ute coal samples (Table 1 and Fig. 5a) indicate oxic and euxinic condition respectively. However, $\mathrm{V} /(\mathrm{V}+\mathrm{Ni})$ ratios predict lower oxygen bottom-water conditions (anoxic) than either $\mathrm{Ni} / \mathrm{Co}$ or $\mathrm{V} / \mathrm{Cr}$ (Peters et al., 2005). The $\mathrm{V} /(\mathrm{V}+\mathrm{Ni})$ ratio can be linked to redox conditions in source rock and low ratios reflect oxicity while high ratios ( $>0.9)$ reflect the anoxic condition in the depositional environment of coal (Peters et al., 2005). The low $\mathrm{V} /(\mathrm{V}+\mathrm{Ni})$ ratio (0.26-0.0.79; Table 1; Fig. 5b) shows that the coal samples are deposited under oxic conditions. This is typical of a coal depositional environment and in agreement with earlier work done by Akande et al., (1992). 
Table 1

Concentration of trace elements contents in Ute and Okaba Coals with certified value.

\begin{tabular}{|c|c|c|c|c|c|c|c|c|c|c|c|c|c|c|c|c|c|}
\hline S/No & $\begin{array}{l}\text { Coal } \\
\text { Mine } \\
\text { Sites }\end{array}$ & $\begin{array}{l}\text { Sample } \\
\text { code }\end{array}$ & Lithology & $\begin{array}{l}\text { As } \\
\text { Ppm }\end{array}$ & $\begin{array}{l}\mathrm{Ba} \\
\mathrm{ppm}\end{array}$ & $\begin{array}{l}\text { Cd } \\
\text { ppm }\end{array}$ & $\begin{array}{l}\text { Co } \\
\text { ppm }\end{array}$ & $\begin{array}{l}\mathrm{Cr} \\
\mathrm{ppm}\end{array}$ & $\begin{array}{l}\mathrm{Cu} \\
\mathrm{Ppm}\end{array}$ & $\begin{array}{l}\mathrm{Hg} \\
\mathrm{Ppm}\end{array}$ & $\begin{array}{l}\text { Mn } \\
\text { Ppm }\end{array}$ & $\begin{array}{l}\mathrm{Ni} \\
\mathrm{ppm}\end{array}$ & $\begin{array}{l}\mathrm{Pb} \\
\mathrm{Ppm}\end{array}$ & $\begin{array}{l}\mathrm{Se} \\
\mathrm{ppm}\end{array}$ & $\begin{array}{l}\text { Mo } \\
\text { ppm }\end{array}$ & $\begin{array}{l}\text { Zn } \\
\text { ppm }\end{array}$ & $\begin{array}{l}\text { V } \\
\text { ppr }\end{array}$ \\
\hline 1 & Okaba & OB-1 & Coal & 5.00 & 78.63 & 0.16 & 1.64 & 10.92 & 7.30 & 2.33 & 20.17 & 3.47 & 3.48 & 3.13 & 0.42 & 3.10 & 13.0 \\
\hline 2 & Ute & UT-1 & Coal & 3.78 & 22.68 & 0.15 & 3.59 & 37.75 & 6.13 & 1.12 & 12.59 & 27.32 & 5.15 & 2.40 & 0.32 & 24.35 & 9.68 \\
\hline
\end{tabular}

Table 2

Concentration of trace elements contents in Ute and Okaba Coals with some elemental ratios

\begin{tabular}{|llllllllllll|}
\hline Sample Name & $\mathrm{Ni}$ & $\mathrm{Co}$ & $\mathbf{V}$ & $\mathrm{Cr}$ & $\mathrm{Cu}$ & $\mathrm{Zn}$ & $\mathrm{V} / \mathrm{Ni}$ & $\mathrm{Ni} / \mathrm{Co}$ & $\mathrm{Cu} / \mathrm{Zn}$ & $\mathrm{V} / \mathrm{Cr}$ & $\mathrm{V} /(\mathrm{V}+\mathrm{Ni})$ \\
\hline Okaba & 3.47 & 1.64 & 13.01 & 10.92 & 7.3 & 3.1 & 3.75 & 2.12 & 2.35 & 1.19 & 0.79 \\
Ute & 27.32 & 3.59 & 9.68 & 37.75 & 6.13 & 24.35 & 0.35 & 7.61 & 0.25 & 0.26 & 0.26 \\
\hline
\end{tabular}

\subsection{Environment of Deposition}

Sulphur content in coal differs from one coal bed to another, it is still an important factor to consider in coal classification. Geochemical studies of sulfur in coals comprise several major aspects relating to the nature and origin of sulfur in coals, including the abundance and distribution of sulfur in coal seams, abundance of sulfur in coal lithotypes and macerals, characteristics and geochemical significance of sulfur-containing organic compounds, sulfur isotopic studies relating to the sources of sulfur in coals, and sedimentary environments controlling the geochemistry of sulfur in coal. variation of sulfur in coals is closely related to the depositional environments of coal seams. For low sulfur coal $(<1 \% \mathrm{~S})$, sulfur is derived primarily from parent plant material. For mediumsulfur (1 to $<3 \% \mathrm{~S}$ ) and high-sulfur ( $\geq 3 \% \mathrm{~S}$ ) coals, there are two major sources of sulfur: 1 ) parent plant material, and 2) sulfate in seawater that flooded peat swamps (Chou, 2012). Abundances of sulfur in coal are largely controlled by the degree of seawater influence during peat accumulation and by postdepositional changes (diagenesis). In high-sulfur coals, seawater sulfate diffuses into the peat, which is subsequently reduced by bacteria into hydrogen sulfide, polysulfides, and elemental sulfur. The total sulfur content of Okaba Coal is $0.85 \%$ and Ute coal is $2.33 \%$ (Table 3 ). These data allow classifying the Okaba and Ute coal as low-sulfur and medium-sulfur coal respectively. Coals with low sulfur content are usually formed in the lacustrine environment based on co-occurrence of fluvio-marine (Ehinola et al., 2012) while high-sulfur coals are deposited in the environment affected by seawater (Chou, 2012). By implication, the sulfur content in the Okaba and Ute coal originated from parent plant material deposited in a lacustrine environment.

Table 3

Total sulfur content in Ute and Okaba Coals from Nigeria

\begin{tabular}{|lllll|}
\hline S/No & Coal Mine Sites & Sample code & Lithology & $\begin{array}{l}\text { Total Sulfur } \\
(\%)\end{array}$ \\
\hline 1 & Okaba & OB-1 & Coal & 0.85 \\
2 & Ute & UT-1 & Coal & 2.33 \\
\hline
\end{tabular}

\subsection{Mineral composition}

The Okaba and Ute coal generally contain a high content of detrital minerals, mainly quartz (25\%) and total clay (52.7) (Table 4). In the analyzed samples, quartz content ranges from significant to moderate. Quartz content is an important factor affecting fracture development; thus, the quartz-rich coal sections are more brittle and therefore make it easy for them to develop fractures. Mineral matters occur in coal in a different mode of occurrences. Many different minerals behave differently. The main minerals are quartz, kaolinite, mullite, and rutile, while the common fluxing minerals are anhydrite, acid plagioclases, $\mathrm{K}$ feldspars, Ca silicates, and hematite (Creelman et al. 2013; Mishra et al. 2016a, b). Table 4 represents the XRD diffractogram result of two samples (Okaba and Ute coal). It indicates the presence of quartz (Q), kaolinite $(K)$, as major mineral phases in both samples. The XRD patterns of both coals are found to show almost similar mineral compositions. The identification of minor minerals only by XRD in a multi-component system like coal is difficult due to the detection limits (normally at about 0.5-1\%) and peak overlapping (Mishra et al., 2016a). Brittle mineral content is an important factor of matrix porosity, micro-fracture development, gas-bearing, and fracturing reformation of shales. The low content of clay minerals and high content of brittle minerals make rocks more brittle. In such circumstances, rocks are more easily to create natural fractures and induced fractures under artificial fracturing forces to form structural joints with tree networks, which is conducive to coal gas exploration (Zou Caineng et al., 2010). Okaba and Ute Coal are rich in brittle minerals, thus conducive to fracturing. 
Table 4

X-ray Diffractogram results in the Nigeria Coals.

\begin{tabular}{|llllllll|}
\hline S/No & Coal Mine Sites & Sample code & Lithology & Quartz & Pyrite & Amorphous & Total Clay \\
\hline 1 & Okaba & OB-1 & Coal & 25.0 & 1.4 & 20.9 & 52.7 \\
\hline 2 & Ute & UT-1 & Coal & 13.8 & 1.2 & 37.7 & 46.1 \\
\hline
\end{tabular}

\subsection{Morphological and Microstructural Properties}

The surface morphology and microstructure of the coal samples were examined by SEM spectroscopy. Figure 4.4 present the high-resolution SEM micrographs of Okaba and Ute coals examined at a magnification of $\times 1100$. The SEM morphological and microstructural analysis presents valuable insights into the chemical composition, pore structure, orientation of particles, and surface composition of solid materials (JEOL 2017; Sengupta et al., 2008). It also provides an indication of the mineral components present in the structure of coals examined during the process (Nyakuma 2019). As observed in Figure 6, the morphology of each coal is characterized by a rough, contoured, and sintered surface with evident macro- or micro-pores along. The coal particles observed in the SEM micrographs also exhibited a glassy sheen at the edges. (figure 6). The glassy or reflective nature of the surface particles observed on the coal surfaces could be due to the presence of aluminosilicate and iron-containing minerals such as quartz, kaolinite, calcite, and pyrite (Akinyemi et al. 2012; Querol et al. 1995; Liu et al. 2005). It is also observed that the Ute and Okaba coals contain copper and zinc (figure 6).

\subsubsection{Evolution Mechanism of Micro-Nano Scale Pores in Coals}

Coal is a complex organic rock that consists of fractures and pores. Pore-fracture systems in coal are very complicated. The main space to store CBM is pore. fracture is the bridge of communication among pores, and it is also the migration channel for gas. Fractures strengthen the connectivity among all kinds of pores so that larger pores and pore-fracture systems can be formed (Ju et al., 2005; Ju and LI, 2009). The evolution of pore structures in coals is related to many factors. The coal's degree of metamorphism, degree of deformation, macerals, minerals, (Pan et al., 2015), and coalification (coal rank) are the main factors influencing the evolution of micro-nano scale pores in coals. (Nie et al., 2015b; Song et al., 2014). Levine, 1993 showed that micropores were related to carbon content and that, in general, micrometer-scale pores increased as coal rank increase. Ozdemir and Schroeder, 2009 also found that as coal rank increases, pore size generally decreases. The physical and chemical properties of coal vary enormously during coalification, (Chen et al., 2015) forming a series of pores from macrometer-scale pores to nanometer-scale pores. The physical properties of coal reservoirs play a very important role in gas adsorption and migration. Cleats and fractures in coals induced by coalification are connected to the development of micro-nano scale pores (Pan et al., 2015), although their formation is complex. Fractures and cleats in lower rank coals were short and randomly distributed, according to Prinz and Littke, 2005; however, they formed better and were spread more regularly in higher rank coals, according to Chen et al., 2015. Temperature, stress, and the combined influence of these two elements are the key indicators of coalification.

The pore or fracture diameter observed on the SEM image of the study area was measured and it was observed that the diameter of pore and fracture from the Okaba and Ute coal ranges from $3,600 \mathrm{~nm}$ to $31,500 \mathrm{~nm}$ and $9,400 \mathrm{~nm}$ to $65,600 \mathrm{~nm}$ respectively.

According to the pore diameter classification method of Hodot, 1996 and Yao et al., 2006:2008 the pores or fractures are divided into two types, that is, microfractures (>10,000 nm), macropores (1000-10,000 nm). Macropores belong to seepage pores, while transition pores and micropores belong to adsorption pores. Gas transport is via laminar flow or turbulent flow in the seepage pores and via capillary condensation, physical adsorption, and diffusion in the adsorption pores Hodot, 1996, Yao et al., 2006:2008. It is to be of note that the fracture in Okaba and Ute coal are wide fracture which extends from the Northwestern part to the southeastern part of the SEM image (Figure 7a and b) which by implication, can serve as a reservoir for coal bed methane (CBM) and the linkage of the fractures and the pores make it to have high permeability that could result to the coal to easily release the gas it's storing upon heating.

\subsection{Coal Gasification (Syngas Extraction)}

Gasification is governed by the same rules that regulate combustion processes. Wood and paper are among the solid biomass fuels suitable for gasification, as are peat, lignite, and coal. All of these solid fuels are essentially carbon-based, with minor amounts of hydrogen, oxygen, and impurities including sulphur, ash, and moisture. Therefore, coals constituents from Ute and Okaba were transformed completely into gaseous forms leaving ashes and inert material as remains.

According to the conventional view of producing gas, the gasification reaction occurs in four zones. Oxidation, reduction, pyrolysis, and distillation are the four zones. The Gasification process is based on the controlled generation of highly flammable gas from air and water vapour. From the bottom to the top of the gas generator, some chain chemical processes are thought to occur. Combustion, reduction, pyrolysis, and drying are examples of these reactions.

In the combustion zone charcoal was ignited to burn and produce flame to ignite the coal, this process is in the presence of air with the aid of a blower which supplies air into the reactor. The coal burns for about 60 minutes where all the water in it has been expelled and the system is closed, which will lead to the producer gas being moved to the reduction zone. The partial combustion products $\mathrm{CO}_{2}$ and $\mathrm{H}_{2} \mathrm{O}$ obtained from the oxidation zone now move through the reduction zone. By absorbing heat from the oxidation zone, $\mathrm{CO}_{2}$ and $\mathrm{H}_{2} \mathrm{O}$ are reduced to carbon monoxide $(\mathrm{CO})$ and hydrogen $\left(\mathrm{H}_{2}\right)$. To boost the carbon/steam gasification reaction, which has larger activation energy, the oxidation zone raises the temperature of the reduction zone. This reaction requires a temperature of $900^{\circ} \mathrm{C}$ and above. Over $90 \%$ of $\mathrm{CO}_{2}$ was reduced to $\mathrm{CO}$ at temperatures above $900^{\circ} \mathrm{C}$. and in the pyrolysis zone, the remaining oil occurs as a stain in the upper part of the reactor due to burning in the absence of air, and syngas and impurities were collected into the cyclone filter where the gas is separated from the impurities. The gas collected is a mixture of $\mathrm{N}_{2}, \mathrm{H}_{2}, \mathrm{CO}_{2}$, and $\mathrm{CH}_{4}$. 
Table 4.5: Experimental Results

Experiments were carried out to find out the amount of gas that coals from Okaba and Ute will generate at maximum temperature.

\begin{tabular}{|llllll|}
\hline $\begin{array}{l}\text { Sample } \\
\text { Name }\end{array}$ & $\begin{array}{l}\text { Sample weight } \\
(\mathrm{kg})\end{array}$ & $\begin{array}{l}\text { Weight of empty } \\
\text { cylinder }(\mathrm{kg})\end{array}$ & $\begin{array}{l}\text { Burning temp. of the } \\
\text { reactor }\left({ }^{\circ} \mathrm{C}\right)\end{array}$ & $\begin{array}{l}\text { Time to complete } \\
\text { combustion }\end{array}$ & $\begin{array}{l}\text { Weight of cylinder after } \\
\text { gasification(kg) }\end{array}$ \\
\hline Okaba & 1 & 5 & $500-1000$ & $1 \mathrm{hr}$ & 6.55 \\
\hline Ute & 1 & 5 & $500-1000$ & $1 \mathrm{hr}$ & 6.09 \\
\hline
\end{tabular}

Temperature of burning coal $=900{ }^{\circ} \mathrm{C}-1000{ }^{\circ} \mathrm{C}$

Temperature of reduction zone $=548{ }^{\circ} \mathrm{C}$

Temperature of drying zone $=131^{\circ} \mathrm{C}$

\subsection{Environmental Impact}

Coal gasification is a well-proven technology that started with the production of coal gas for urban areas, progressed to the production of fuels, such as oil and synthetic natural gas (SNG), chemicals, and most recently, to large-scale Integrated Gasification Combined Cycle (IGCC) power generation. IGCC is an innovative electric power generation concept that combines modern coal gasification technology with a both gas turbine (Brayton cycle) and steam turbine (Rankine cycle) power generation. The technology is highly flexible and can be used for new applications, as well as for repowering older coal-fired plants, significantly improving their environmental performance. IGCC provides feedstock and product flexibility, greater than 40 percent thermal efficiency, and very low pollutant emissions. IGCC plants have achieved the lowest levels of criteria pollutant air emissions (NOx, SOx, CO, PM10) of any coal-fueled power plants in the world. Emissions of trace hazardous air pollutants are extremely low, compared with those from direct-fired combustion plants that use advanced emission control technologies. Discharge of solid byproducts and wastewater is reduced by roughly $50 \%$ versus other coal-based plants, and the by-products generated (e.g., slag and sulfur) are environmentally benign and can potentially be sold as valuable products. Another significant environmental benefit is the reduction of carbon dioxide $\left(\mathrm{CO}_{2}\right)$ emissions, by at least $10 \%$ per equivalent net production of electricity, due to higher operating efficiency compared to conventional pulverized coal-fired power plants.

The EPA-designated criteria air pollutants produced by the conversion of coal and other solid carbonaceous fuels (e.g., petroleum coke) in gasification-based power cycles are $\mathrm{SO}_{2}, \mathrm{NOx}$, particulates, and $\mathrm{CO}$. The environmental benefits of the gasification steam from the capability to achieve extremely low $\mathrm{SO}_{\mathrm{x}}, \mathrm{NO}_{\mathrm{x}}$ and particulate emissions from burning coal-derived gases sulfur in coal, for example, is converted to hydrogen sulfide and can be captured by processes present use in the chemical industry. Among the environmental benefit of coal gasification is the production of significantly lower quantities of criteria air pollutants, reduce the environmental impact of waste disposal because it can use waste products as feedstocks-generating valuable products from materials that would otherwise be disposed of as wastes, gasification's byproducts are non-hazardous and are readily marketable, gasification plants use significantly less water than traditional coal-based power generation, and can be designed so they recycle their process water, discharging none into the surrounding environment, carbon dioxide $\left(\mathrm{CO}_{2}\right)$ can be captured from an industrial gasification plant using commercially proven technologies. In fact, since 2000 , the Great Plains Substitute Natural Gas plant in North Dakota has been capturing the same amount of $\mathrm{CO}_{2}$ as a $400 \mathrm{MW}$ coal power plant would produce and sending that $\mathrm{CO} 2$ via pipeline to Canada for Enhanced Oil Recovery.

\section{Conclusions}

Coal samples from the study area (Okaba and Ute) are deposited in an oxic condition and originate from parent plant material. The coal samples are capable of storing gas which in turn can be extracted and used by gasification method which has minimal environmental effect due to the fact that the gasification plant reduces $\mathrm{CO} 2$ emission by $90 \%$ as compared with direct combustion of coal.

\section{Declarations}

Acknowledgements the Authors gratefully acknowledge Mr Abiona who helped with the fabrication. The Authors are also grateful to Mr Mohammad Sajjad from Pakistan for his support throughout the research work.

Author contributions OAE: conceptualisation, editing and fact checking KJE: sample collection, data analysis and experimentation of the fabricated plant, original manuscript draft and writing review, IAO: experimental design and geochemical result interpretation; OAF: modification of fabrication design, OAO: revisions, editing, and proofing.

Funding This research did not receive any form of funding or financial support from any organization.

Availability of data and materials All the data in the manuscript is presented in the form of tables and figures.

\section{Compliance with ethical standards}

Conflict of interest The authors declare no conflict of interest whatsoever. 


\section{References}

1. Adedosu TA, Adedosu HO, \& Adebiyi FM (2007) Geochemical and mineralogical significance of trace metals in Benue Trough coals, Nigeria. Journal of Applied Sciences 7(20):3101-3105

2. Ajayi TR, Oyawale AA, Islander FY, Asubiojo OI, Klein DE, Adediran Al (2006) Trace and rare earth elements geochemistry of Oshosun sediments of Dahomey basin, Southwestern Nigeria. Journal of Applied Science 6:2067-2076

3. Akande SO, Hoffknecht A, Erdtmann BD Upper Cretaceous and Tertiary Coals from Southern Nigeria: Composition, Rank Depositional Environments and their Technological properties. Bull. Nig. Assoc. Pet. Geol., 1992, I.7, 26-28

4. Akande SO, Hoffknecht A, Erdtmann BD (1992a) Rank and petrographic composition of selected Upper Cretaceous and Tertiary coals of southern Nigeria. Intern Journ Coal Geol pp 20:209-224

5. Akinyemi S, Gitari W, Akinlua A, Petrik L (2012) Mineralogy and geochemistry of sub-bituminous coal and its combustion products from Mpumalanga Province, South Africa. In: Analytical Chemistry. InTech

6. Algeo TJ, Maynard JB (2004) Trace element behavior and redox facies analysis of core shales of Upper Pennsylvanian Kansas-type cyclothems. Chem Geol 206:289-318

7. Barwise AJG (1990) Role of nickel and vanadium in petroleum classification. Energy Fuels 4:647-652

8. Chen Y, Tang DZ, Xu H et al (2015) Pore and fracture characteristics of different rank coals in the eastern margin of the Ordos Basin, China. J Nat Gas Sci Eng 26:1264-1277

9. Chou L (1984) Relationship between geochemistry of coal and the nature of strata overlying the Herrin coal in the Illinois Basin, USA. Memoir of Geological Society of China 6:269-280

10. Chou CL (2012) Sulfur in coals: A review of geochemistry and origin. - Intern J Coal Geology 100:1-13

11. Creelman RA, Ward CR, Schumacher G, Juniper L (2013) Relation between coal mineral matter and deposit mineralogy in pulverized fuel furnaces. Energy Fuels 27:5714-5724

12. Creelman RA, Ward CR, Schumacher G, Juniper L (2013) Relation between coal mineral matter and deposit mineralogy in pulverized fuel furnaces. Energy Fuels 27:5714-5724

13. Ehinola OA, Oluwajana OA, Nwabueze E (2012) Depositional Environment, Geophysical Mapping and Reserve Estimation of Limestone Deposit in Arimogija Okeluse Area, Southwestern Nigeria Research Journal in Engineering and Applied Sciences 1 (1) (2012) 7-11

14. Ehinola OA, Oluwajana A, Adekoya AT (2012) Geophysical investigation and reserve estimation of a coal seam in Ute area, South-western Nigeria. Petrol Coal 54:252-259

15. Ehinola OA, Ekweozor CM, Oros DR, Simoneit BRT, Geology (2002) Geochemistry and Biomarker Evaluation of Lafia-Obi Coal, Benue Trough Nigeria. Fuel 81:219-233

16. Ford SO (1981) The Economic Mineral Resources of the Benue Trough. Earth Evol Sci 1:2, 154-163

17. Goodarzi F (1987) The concentration of elements in lacustrine coals from zone A Hat Creek Deposit No. 1, British Columbia, Columbia, Canada. Int J Coal Geol 8:247-268

18. Goodarzi F (1988) Elemental distribution in coal seams at the Fording coal mine, British Columbia, Columbia, Canada. Chem Geol 68:129-154

19. Hart RJ, Leahy RM (1983) The geochemical characteristics of coal seams from the Witbank Basin. Special Publication of the Geol Soc Afr 7:169-174

20. Hatch JR, Leventhal JS (1992) Relationship between inferred redox potential of the depositional environment and geochemistry of the Upper

Pennsylvanian (Missourian) stark shale member of the Dennis Limestone, Wabaunsee County, Kansas, USA. Chem Geol 99:65-82

21. Hodot BB (1996) Outburst of Coal and Coalbed Gas. China Industry Press, Beijing (In Chinese)

22. JEOL (2017) JEOL-JSM IT 300 LV SEM Microscope. JEOL Germany. http://bit.ly/2khv3uX. Accessed 4th December 2017

23. Jones B, Manning DAC (1994) Comparison of geochemical indices used for the interpretation of palaeoredox conditions in ancient mudstones. Chem Geol 111:111-129

24. Ju YW, Jiang B, Hou QL, Wang GL (2005) Relationship between nanoscale deformation of coal structure and metamorphic deformed environments. Chin Sci Bull 50(16):1785-1796

25. Ju YW, Li XS (2009) New progress in the study of ultrastructure of tectonically deformed coal. Progress Nat Sci 19(02):131-140

26. KIllops SD, Killops VJ (2005) Introduction to Organic Geochemistry. 2nd Edition, Blackwell Science Publishing Limited

27. Levine JR (1993) Coalification: the evolution of coal as source rock and reservoir. In: Law, B.E., Rice, D.D. (Eds.), Hydrocarbons from Coal. American Association of Petroleum Geologists. AAPG Studies in Geology, vol. 38, pp. 39-77

28. Liu G, Vassilev SV, Gao L, Zheng L, Peng Z (2005) Mineral and chemical composition and some trace element contents in coals and coal ashes from Huaibei coalfield. China Energy Conversion Management 46:2001-2009

29. Loison R, Foch P, Boyer A, 'Coke quality and production', 2nd eds., Butterworths, London(1989)

30. Mishra V, Bhowmick T, Chakravarty S, Varma AK, Sharma M (2016a) Influence of coal quality on combustion behaviour and mineral phases transformations. Fuel 186:443-455

31. Mishra V, Sharma M, Chakravarty S, Banerjee A (2016b) Changes in organic structure and mineral phases transformation of coal during heat treatment on the laboratory scale. Int J Coal Sci Technol 3:418-428 
32. Moldowan JM, Sundararaman P, Schoell M (1986) Sensitivity of biomarker properties to depositional environment and/or source input in the Lower Toarcian of S. W. Germany. Organic Geochemistry, 10: 915-926

33. NCC (Nigeria Coal Corporation). Information on the Nigerian Coal Industry, Enugu; 1982, 10

34. NCC (Nigeria Coal Corporation) (1997) Nigerian Coal Corporation Information Manual, 7. OAC/AEC Trade Fair, th

35. Nie BS, Liu XF, Yang LL et al (2015b) Pore structure characterization of different rank coals using gas adsorption and scanning electron microscopy. Fuel 158:908-917

36. Nyakuma BB (2019) Physicochemical, Geomineralogical, and Evolved Gas Analyses of Newly Discovered. Nigerian Lignite Coals Coke Chemistry 62:394401

37. Obaje NG, Wehner H, Scheeder G, Abubakar MB, Jauro A (2004) Hydrocarbon prospectivity of the Nigerian Inland basins: From the viewpoint of organic petrology and organic geochemistry. AAPG Bull 88(3):325-353

38. Obaje NG, Abaa SI, Najime T, Suh CE A Brief Petrographic Review on Nigerian Coal Resources. In: Elueze, A.A., ed., Journal of Mining and Geology, 1999, $36,1,19-28$

39. Obaje NG, Ligouis B (1996) Petrographic Evaluation of the Depositional Environments of the Cretaceous Obi/Lafia Coal Deposits in the Benue Trough of Nigeria. Journ of Afr Earth Sci 22:157-171

40. Obaje NG (1994) Coal Petrography, Microfossils, and Palaeoenvironments of Cretaceous Coal Measures in the Middle Benue Trough of Nigeria. Tubinger Mikropalaontologische Mitteilungen 11:1-165

41. Orem WH, Finkelman RB (2003) Coal formation and geochemistry. In: Mackenzie FT (ed) Sediments, Diagenesis, and Sedimentary Rocks, Volume 7, Treatise on Geochemistry. Elsevier Pergamon, Oxford, pp 191-222

42. Ozdemir E, Schroeder K (2009) Effect of Moisture on Adsorption Isotherms and Adsorption Capacities of CO2 on Coals. Energy Fuels $23(5): 28212831$. doi:10.1021/ef801126a

43. Pan JN, Zhao YQ, Hou QL, Jin Y, Transport. Porous. Med. 107, 543 (2015) Macromolecular and pore structures of Chinese tectonically deformed coal studied by atomic force microscopy. Fuel 139(1): 94-101

44. Peters KE, Walters CC, Moldowan JM (2005) The biomarker guide, 2nd edition. Cambridge University Press, New York, 1155p

45. Prinz D, Littke R (2005) Development of the micro-and ultramicroporous structure of coals with rank as deduced from the accessibility to water. Fuel 84:1645-1652

46. Querol X, Fernández-Turiel J, López-Soler A (1995) Trace elements in coal and their behaviour during combustion in a large power station Fuel 74:331343

47. Saez R, Moreno C, Gonzalez F, Almodovar GR (2011) Black shales and massive sulfide deposits: Causal or causal relationships? Insights from Rammelsberg, Tharsis, and DraaSfar. Miner Deposita 46(5/6):585-614

48. Sengupta P, Saikia PC, Borthakur PC (2008) SEM-EDX characterization of an iron-rich kaolinite clay. Journal of Scientific Research 67:812-818

49. Simpson A (1954) The Nigeria Coalfield: The Geology of Parts of Owerri and Benue Provinces. Bull Geol Surv Nigeria 24:85

50. Song XX, Wang SQ, Tang YG, Li W, Zeng FG, Xiang JH (2014) Pore structure in tectonically deformed coals by small-angle X-ray scattering. J China Coal Soc 39(4):719-724

51. Tribovillard N, Algeo TJ, Lyons T, Riboulleau A (2006) Trace metals as paleoredox and paleoproductivity proxies: An update. Chem Geol 232:12-32

52. Wilson RC, Bain AD The Nigeria Coalfield Section II. Parts of Onitsha and Owerri Provinces. With an appendix by L.F. Spath on the Albian Ammonoidea of Nigeria, 1928, 12, 54

53. Yao YB, Liu DM, Huang WH, Tang DZ, Tang SH (2006) Study on Pore-Fracture System of Coal Reservoirs and Coalbed Methane Production Performance in Lianghuai Coalfield. J China Coal Soc 2:163-168. (in Chinese with English abstract)

54. Yao Y, Liu D, Tang D, Tang S, Huang W (2008) Fractal characterization of adsorption pores of coals from North China: An investigation on $\mathrm{CH}_{4}$ adsorption capacity of coals. Int J Coal Geol 73:27-42

55. Zou Caineng D, Dazhong, Wang S (2010) Geological characteristics, formation mechanism, and resource potential of shale gas in China. Pet Explor Dev 37:641-653 (in Chinese)

\section{Figures}




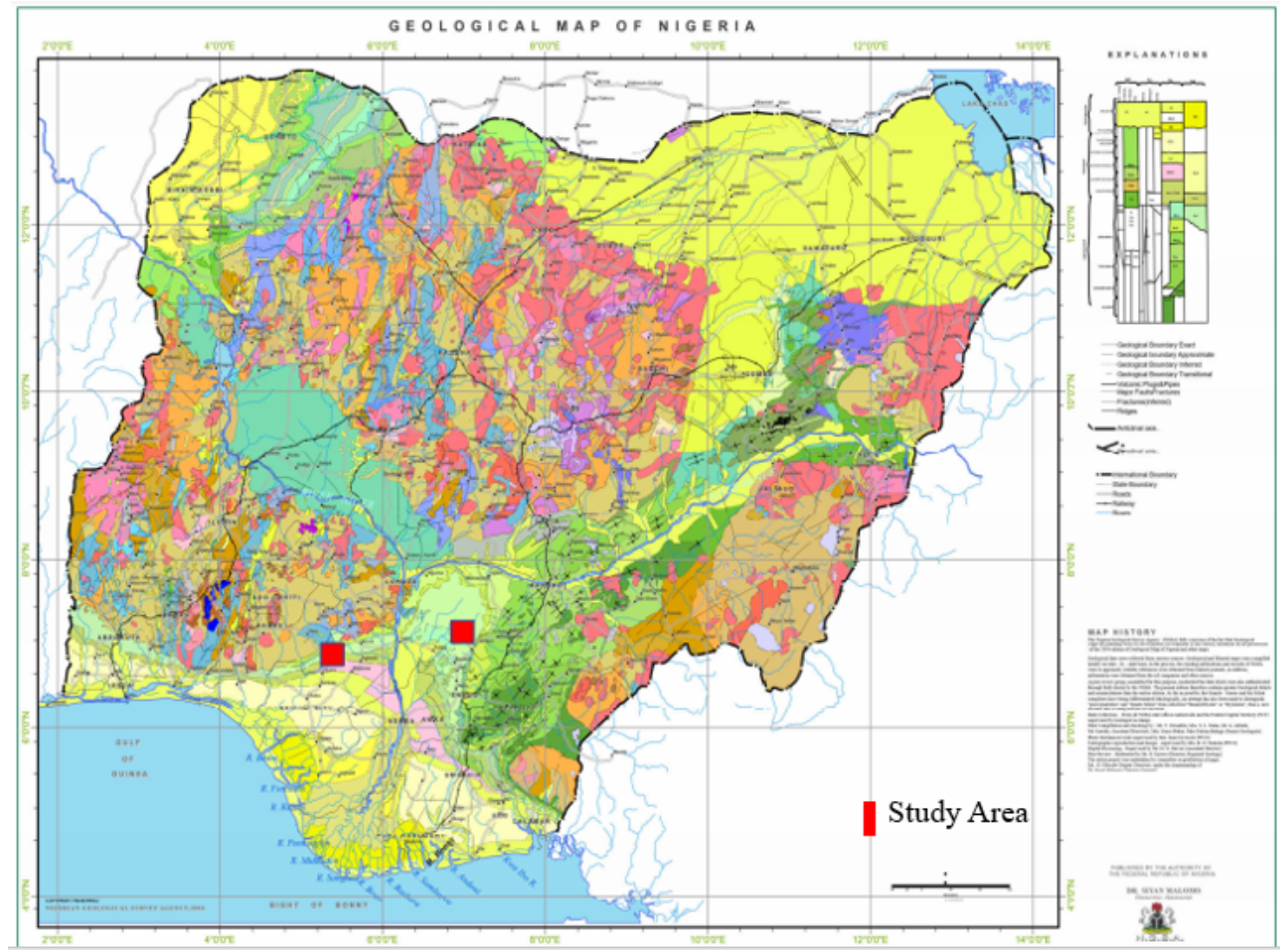

Figure 1

Map of Nigeria showing sample location

\begin{tabular}{|c|c|c|c|}
\hline \multirow{2}{*}{ હ્छ } & 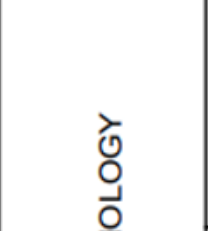 & 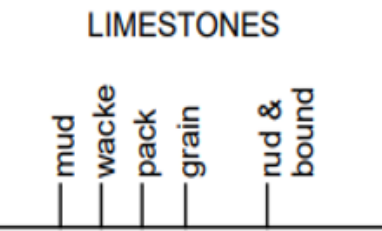 & \multirow{2}{*}{ 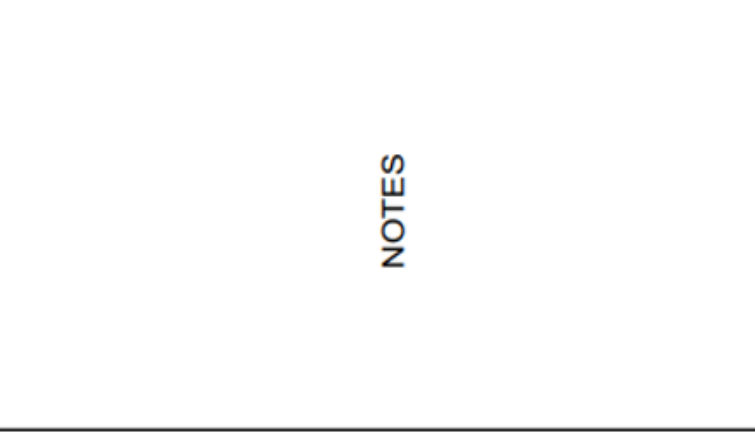 } \\
\hline & $\stackrel{\Xi}{\Xi}$ & 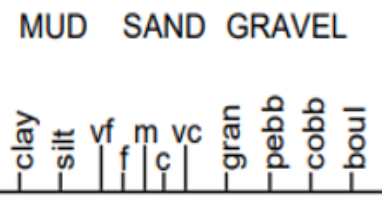 & \\
\hline 1 & 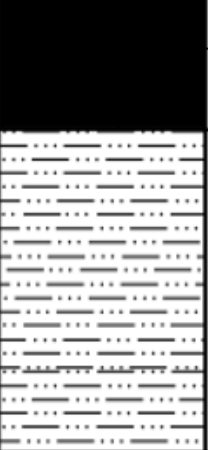 & UT-1 & $\begin{array}{l}\text { Thin-thick dark coal seam. The coal becomes silty } \\
\text { towards the coal-silt contact } \\
\text { Massive, slightly ferruginous at some interval and } \\
\text { moderately hard siltstone with a gradual contact with the } \\
\text { coal. }\end{array}$ \\
\hline
\end{tabular}

Figure 2

Lithologic description of Ute coal. 


\begin{tabular}{|l|l|l|}
\hline & & \\
\end{tabular}

Figure 3

Lithologic description of Okaba coal

A

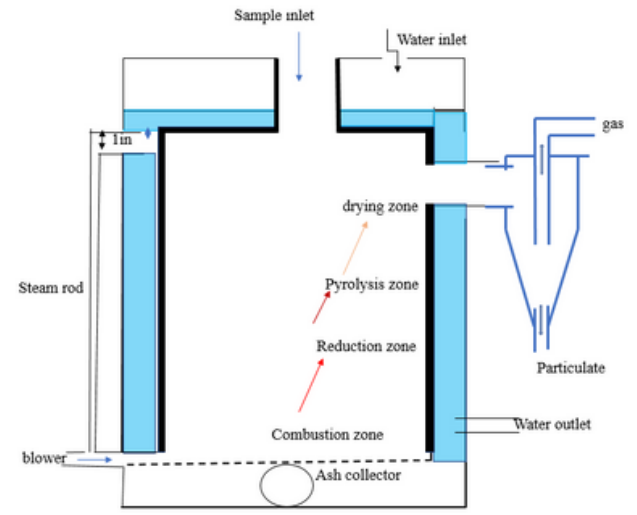

B

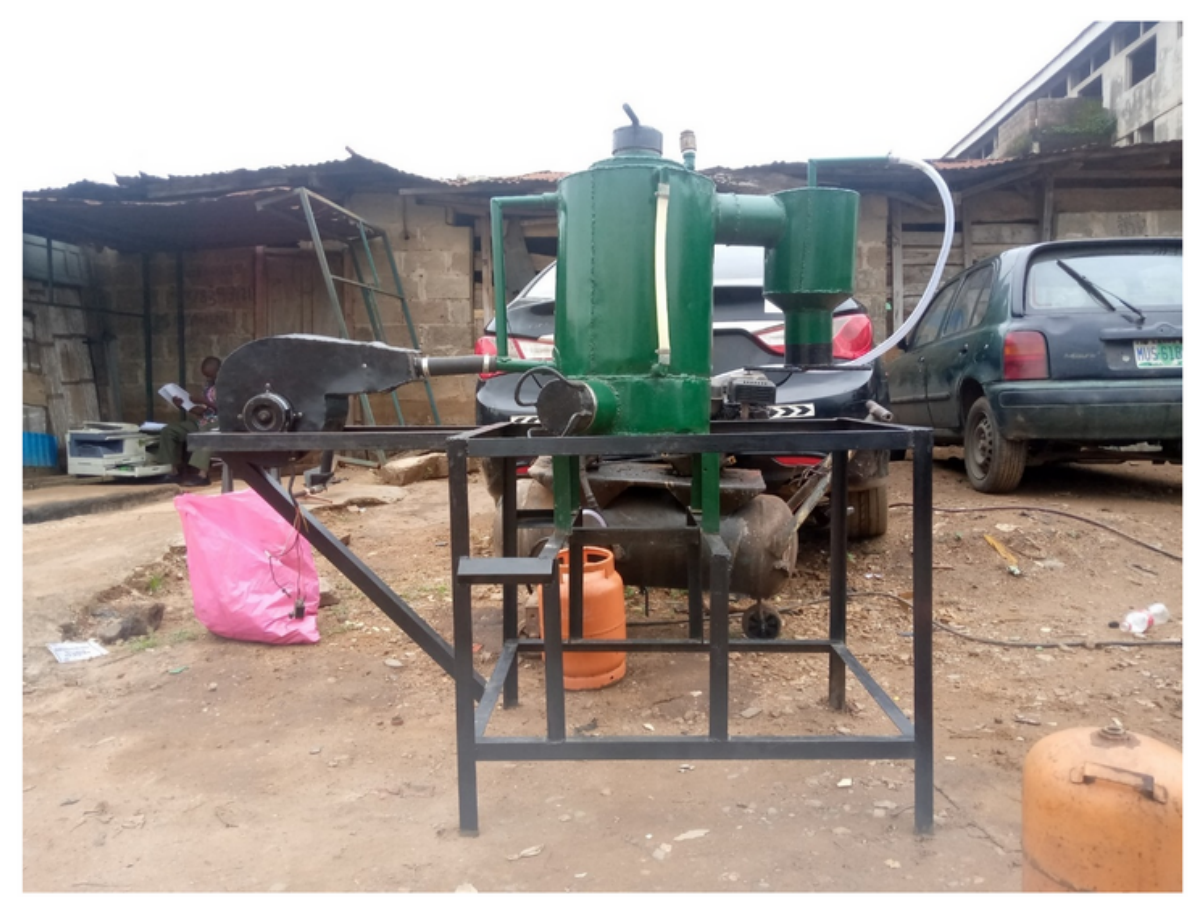

Figure 4

a: Complete assembly of coal gasification plant prototype. b: Complete assembly of the gasification plant. 

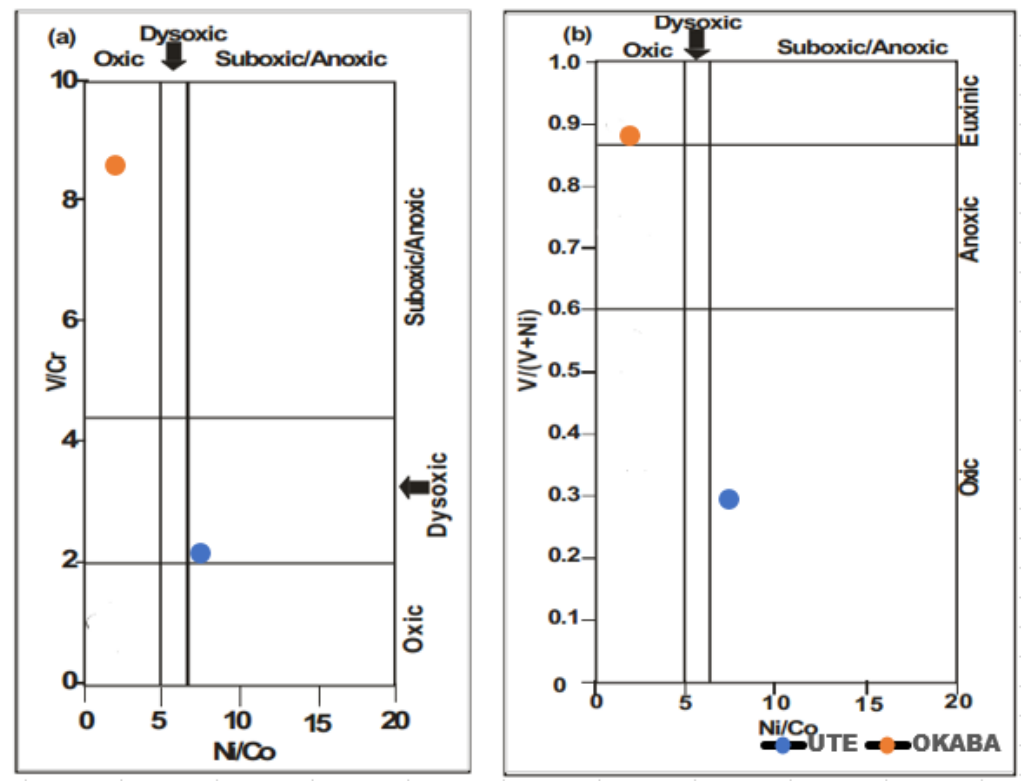

Figure 5

Cross plots of (a) V/Cr versus $\mathrm{Ni} / \mathrm{Co}$ and (b) $\mathrm{V} /(\mathrm{V}+\mathrm{Ni})$ versus $\mathrm{Ni} / \mathrm{Co}$ (Ranges for $\mathrm{V} / \mathrm{Cr}$ and $\mathrm{Ni} / \mathrm{Co}$ are from Jones and Manning (1994) while $\mathrm{V} /(\mathrm{V}+\mathrm{Ni}$ ) are from Hatch and Leventhal (1992).

A
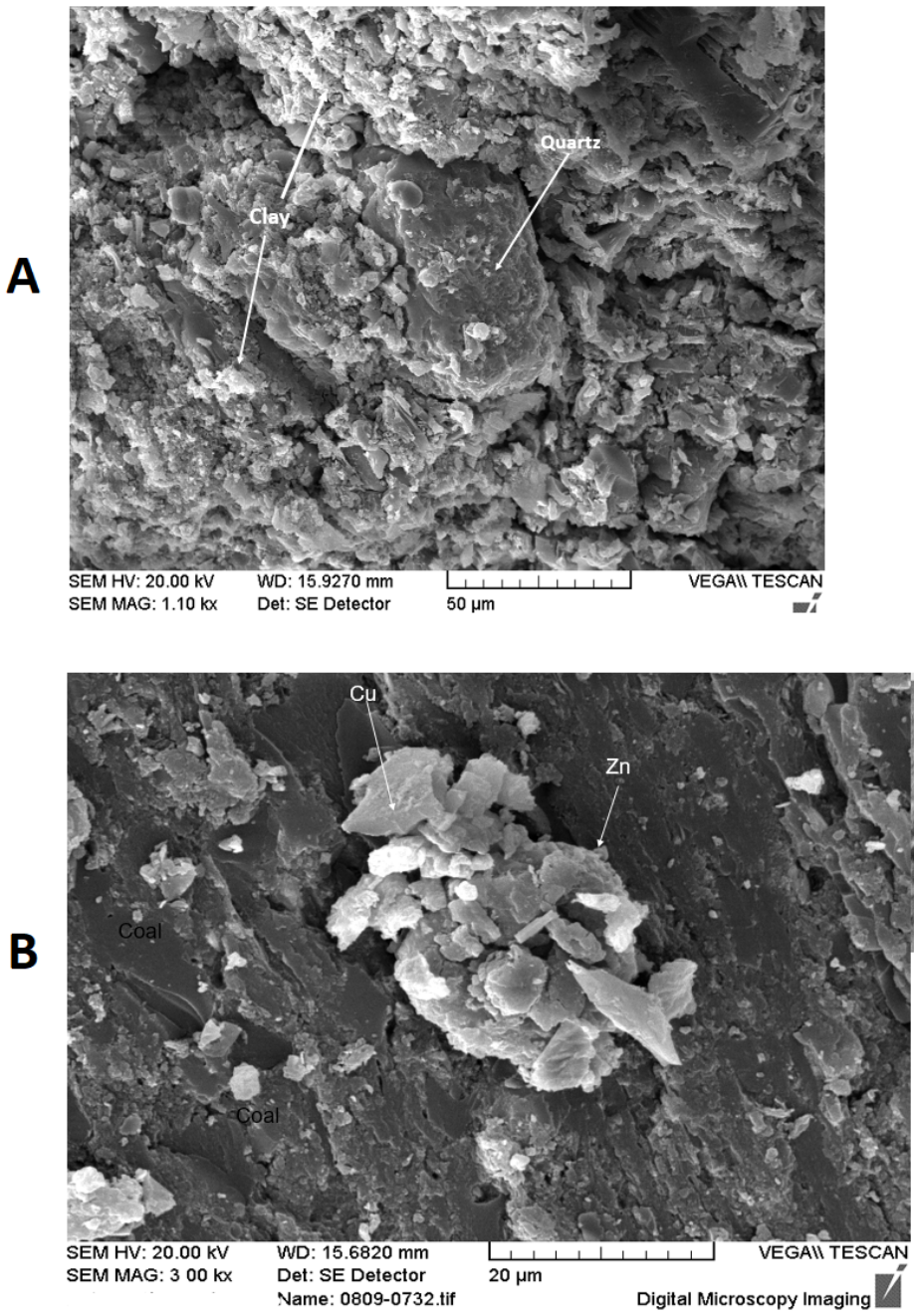

\section{Figure 6}

$6 a \& b$ : SEM Image of minerals from Ute and Okaba respectively showing the mineral distribution 

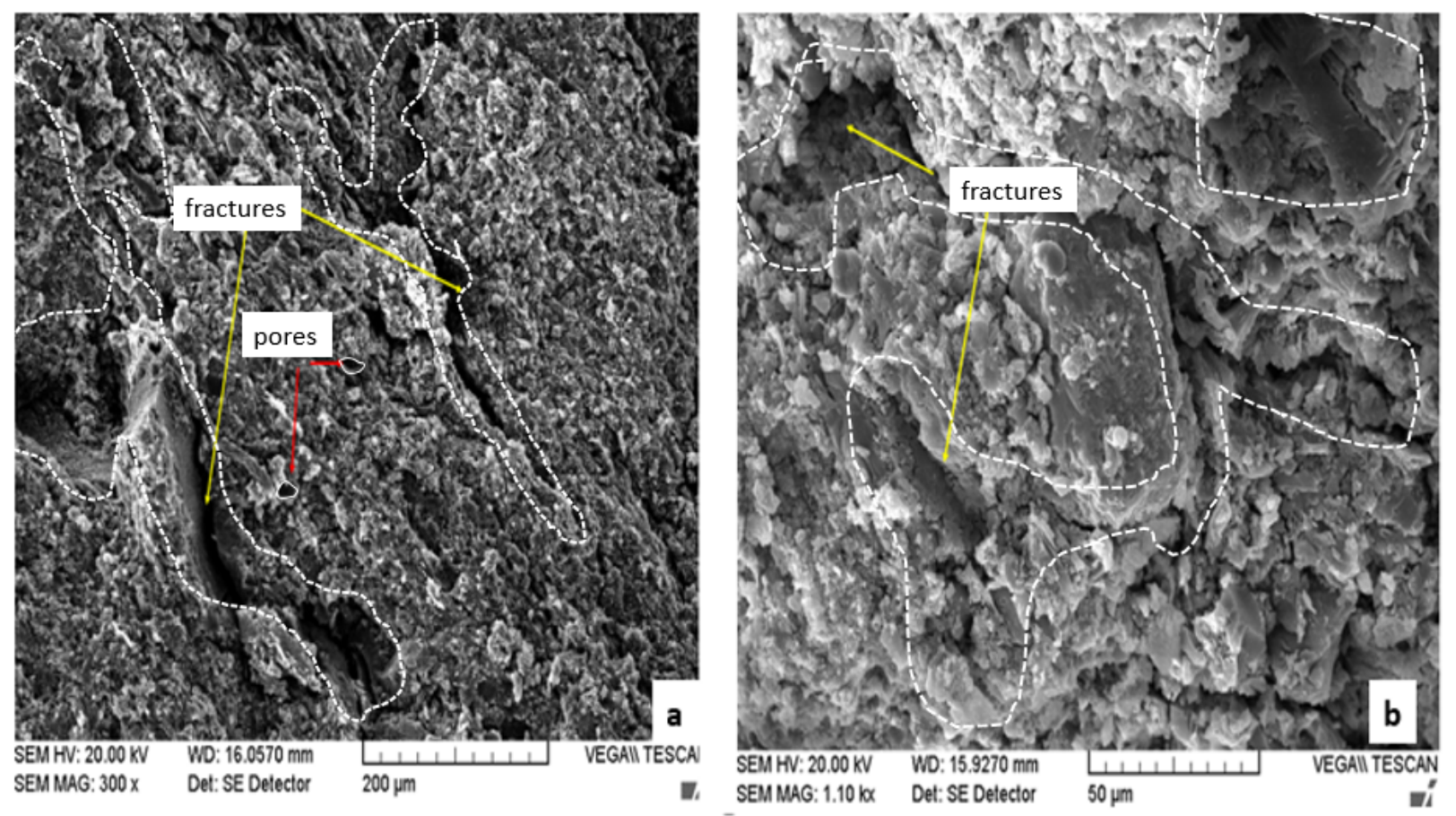

\section{Figure 7}

SEM image of (a)Ute and (b) Okaba coal showing fractures and pores 